\title{
FOTODEGRADASI PEWARNA TEKSTIL KRISTAL VIOLET TERKATALIS ZnO/ZEOLIT Y SECARA SPEKTROFOTOMETRI UV-VIS
}

\author{
R. Supriyanto ${ }^{*}$, Silvi Puteri Anggraini ${ }^{1}$, Syaiful Bahri ${ }^{1}$, Mita Rilyanti ${ }^{1}$ \\ ${ }^{1}$ Jurusan Kimia FMIPA Universitas Lampung, Bandar Lampung \\ r.supriyanto@fmipa.unila.ac.id
}

\begin{tabular}{|c|}
\hline Artikel Info \\
\hline $\begin{array}{l}\text { Diterima } \\
\text { tanggal } \\
01.12 .2020\end{array}$ \\
\hline $\begin{array}{l}\text { Disetujui } \\
\text { publikasi } \\
\text { tanggal } \\
\text { 30.04.2021 }\end{array}$ \\
\hline $\begin{array}{l}\text { Kata kunci : } \\
\text { Kristal Violet, } \\
\text { UV-Vis, } \\
\text { Fotoreduksi, } \\
\text { ZnO/Zeolit Y, } \\
\text { Impregnasi }\end{array}$ \\
\hline
\end{tabular}

\section{ABSTRAK}

Telah dilakukan penelitian fotoreduksi pewarna tekstil kristal violet menggunakan katalis $\mathrm{ZnO} /$ Zeolit $\mathrm{Y}$. Hasil Penelitian diperoleh katalis $\mathrm{ZnO} / \mathrm{Zeolit}$ $\mathrm{Y}$ berupa serbuk berwarna putih dengan metode impegnasi. Karakteristik $\mathrm{ZnO} /$ Zeolit Y didapatkan dengan metode X-Ray Diffraction (XRD) dan Scanning Electron Microscopy (SEM). Uji linieritas kristal violet diperoleh nilai $\mathrm{R}^{2}$ sebesar 0,998 . Uji presisi memberikan nilai \% RSD sebesar $1,77 \%$. Nilai percent recovery dari metil violet sebesar $107,151 \%$. Hasil perhitungan dari Limit of Detection (LoD) memberikan nilai 0,0571 ppm dan nilai Limit of Quantity (LoQ) sebesar 0,1906 ppm. Pada penelitian ini intensitas cahaya pada lampu pijar yang digunakan untuk degradasi sebesar 8000 Lux. Didapatkan waktu optimum fotodegradasi Kristal violet pada menit 150 dengan kondisi pH 5. Zeolit Y tanpa $\mathrm{ZnO}$ mampu menurunkan konsentrasi kristal violet mencapai 53,351\% (pada penambahan 1,0 mg). ZnO/Zeolit $\mathrm{Y}$ sebagai katalis mampu menurunkan konsentrasi dari kristal violet mencapai 81,996\% (pada penambahan 1,0 mg). Berdasarkan hasil pengukuran menunjukkan bahwa fotodegradasi kristal violet dengan bantuan katalis $\mathrm{ZnO} /$ Zeolit $\mathrm{Y}$ dapat meningkatkan persen penurunan konsentrasi kristal violet terlarut.

\section{ABSTRACT}

Photoreduction of crystal violet textile dye has been carried out using $\mathrm{ZnO}$ / Zeolite Y catalyst. The white powder of $\mathrm{ZnO} /$ Zeolite $\mathrm{Y}$ catalyst was obtained by impregnation method. Characterization data of the catalyst was collected by the X-Ray Diffraction (XRD) and Scanning Electron Microscopy (SEM) methods. Linearity test of crystal violet obtained R2 value of 0.998 . The precision test gives a value of $\%$ RSD of $1.77 \%$. The percent recovery value of crystal violet is $107.151 \%$. The calculation result of the Limit of Detection (LoD) gives a value of $0.0571 \mathrm{ppm}$ and a Limit of Quantity (LoQ) value of 0.1906 ppm. In this study the light intensity of incandescent lamps used for degradation was 8000 Lux. The optimum time for photodegradation of crystal violet was 150 minutes with a $\mathrm{pH}$ of 5 . ZnO/Zeolite $\mathrm{Y}$ as a catalyst can reduce the concentration of crystal violet reaching $81.996 \%$ (at the addition of $1.0 \mathrm{mg}$ ). Based on the measurement results show that photodegradation of crystal violet with the help of $\mathrm{ZnO} /$ Zeolite $\mathrm{Y}$ catalyst occurs can increase the percent decrease in the concentration of dissolved crystal violet.

http://dx.doi.org/10.23960/aec.v6.i1.2021.p33-45

Anal.Environ.Chem. 


\section{PENDAHULUAN}

Perkembangan industri tekstil saat ini mengalami kemajuan yang cukup cepat, sehingga banyak menimbulkan dampak positif terhadap perekonomian masyarakat dan kegiatan di bidang sandang ini juga memberikan dampak negatif terhadap lingkungan. Saat ini penggunaan pewarna sintetis dalam industri tekstil sudah tidak dapat dihindari lagi, mengingat harganya yang murah, warnanya lebih tahan lama, dan pilihan warna yang lebih beragam jika dibandingkan dengan pewarna alami. Senyawa kimia yang terikat dalam limbah tersebut akan mengganggu kehidupan biota dalam lingkungan karena sifatnya beracun, menyebabkan kanker dan mutagenik bila masuk dalam tubuh manusia dan akhirnya berpengaruh terhadap kesehatan manusia (Youssef, et al., 2016).

Metil violet merupakan zat warna jenis trifenil metana yang memberikan warna ungu. Zat warna ini memiliki kestabilan yang tinggi sehingga sulit terdegradasi di ekosistem perairan (Astuti dkk., 2017 dan Blackburn and Burkinshaw, 2002). Selain itu, metil violet yang termasuk dalam jenis zat warna kationik bersifat toksik, mutagenik dan karsinogenik. Kandungan metil violet yang tinggi di perairan juga dapat mengurangi intensitas cahaya yang masuk ke wilayah perairan (Rahchamani et.al., 2011). Mengingat efek yang ditimbulkan oleh zat warna tekstil Kristal Violet terhadap lingkungan dan makhluk hidup di dalamnya, perlu dilakukan berbagai upaya untuk meminimalisir limbah zat warna tersebut sebelum dibuang ke dalam system perairan.

Semakin berkembangnya teknologi berbagai teknik atau metode penanggulangan limbah tekstil telah banyak dikembangkan, salah satu metode yang digunakan yaitu metode adsorpsi. Metode Adsorpsi dianggap kurang efektif karena zat warna tekstil masih terakumulasi di dalam adsorben yang akan menimbulkan persoalan baru. Metode untuk pengolahan zat warna tekstil yang dikenal seperti metode fotodegradasi. Fotodegradasi (fotokatalisis-degradasi) adalah suatu proses peruraian suatu senyawa dengan bantuan energi foton atau cahaya. Senyawa yang diurai biasanya adalah senyawa organik. Prinsip fotodegradasi yaitu adanya loncatan elektron dari pita valensi ke pita konduksi pada bahan semikonduktor ketika dikenai suatu energi foton (Fatimah dan Wijaya, 2005). Semikonduktor $\mathrm{ZnO}$ memiliki keuntungan dibandingkan dengan $\mathrm{TiO}_{2}$ karena $\mathrm{TiO}_{2}$ membutuhkan energi yang lebih besar dalam proses fotodegradasinya dan harganya cukup 
mahal (Singh, 2009). Metode fotodegradasi akan meyebabkan zat warna terurai menjadi komponen-komponen yang lebih sederhana dan lebih aman untuk lingkungan.

Dilakukan penelitian tentang studi fotodegradasi pewarna Kristal violet terkatalis $\mathrm{ZnO} /$ Zeolit Y pada daerah sinar polikromatis (sinar tampak) secara spektrofotometri Ultra Violet (UV) Visibel (Vis), pada penelitian ini ditentukan waktu optimum, pH optimum degradasi Kristal violet, pengaruh penambahan katalis Zeolit-Y tanpa $\mathrm{ZnO}$ serta pengaruh penambahan katalis $\mathrm{ZnO} /$ Zeolit Y.

\section{METODE}

\section{Alat dan Bahan}

Alat-alat yang akan digunakan dalam penelitian ini adalah alat-alat gelas dan alat pendukung lainnya, Spektrofotometer UV-Vis, pH meter, Scanning Electron Microscopy (SEM), XRD, reaktor fotodegradasi sinar tampak, pengaduk magnit, lux meter, tanur, dan neraca analitik.Bahan-bahan yang digunakan dalam penelitian ini adalah pewarna tekstil Kristal Violet, zeolit-Y, $\mathrm{ZnSO}_{4} 2 \mathrm{M}, \mathrm{ZnO} / \mathrm{Zeolit} \mathrm{Y}, \mathrm{H}_{2} \mathrm{SO}_{4}$ 0,01 M, NaOH 0,01 M dan akuades.

\section{Prosedur}

\section{Pembutan Larutan Baku Pewarna Kristal Violet}

a. ditimbang 1,0 gram pewarna Kristal Violet, dilarutkan menggunakan akuades dalam labu takar hingga tanda batas $1000 \mathrm{~mL}$. Diperoleh larutan pewarna tekstil Kristal Violet 1000ppm.

b. diencerkan menjadi $50 \mathrm{ppm}$.

c. ditentukan panjang gelombang $(\lambda)$ optimum larutan pewaran tekstil Kristal Violet.

d. dibuat kurva kalibrasi dengan membuat variasi larutan baku 1, 3, 5, 7, dan 9 ppm. Ukur absorbansi deret larutan baku tersebut pada panjang gelombang optimum.

\section{Penyiapan Katalis $\mathrm{ZnO} /$ Zeolit $\mathrm{Y}$}

Ditimbang 5 gram Zeolit Y dan timbang $\mathrm{ZnSO}_{4}$ sebanyak 3,22 gram. $\mathrm{ZnSO}_{4}$ sebanyak 3,22 gram tersebut diencerkan dalam $100 \mathrm{~mL}$ akuabides, kemudian 2 bahan tersebut dimasukkan ke dalam gelas kimia $400 \mathrm{~mL}$ lalu dan diaduk menggunakan magnetik stirer selama \pm 2 jam, hasil tersebut kemudian dioven 24 jam pada suhu $80{ }^{\circ} \mathrm{C}$. Hasil oven di gerus menggunakan alu dan mortar sampai halus, kemudian serbuk $\mathrm{ZnO} /$ Zeolit $\mathrm{Y}$ tersebut sebagian dikalsinasi 2 jam pada 
suhu $600{ }^{\circ} \mathrm{C}$ dan sebagian di simpan dalam wadah botol film. Hasil kalsinasi di karakterisasi menggunakan XRD dan SEM.

\section{Penentuan Waktu Optimum Degradasi Kristal Violet}

$100 \mathrm{~mL}$ larutan pewarna Kristal Violet 5 ppm dimasukkan ke dalam reaktor fotoreduksi dan diaduk dengan kecepatan pengadukan 80 rpm dengan variasi waktu selama 0; 30; 60; 90; $120 ; 150 ; 180 ; 210$ dan 240 menit. Diukur absorbansi larutan menggunakan spektrofometer UVVis, diperoleh waktu optimum degradasi Kristal Violet.

\section{Penentuan pH Optimum Degradasi Kristal Violet}

$100 \mathrm{~mL}$ larutan pewarna Kristal Violet 16 ppm diukur nilai pHnya menggunakan pH meter. Selanjutnya dengan menggunakan kuat cahaya dan waktu optimum yang telah diperoleh, kemudian ditentukan pengaruh $\mathrm{pH}$ dengan variasi $\mathrm{pH} 5,0 ; 6,0 ; 7,0 ; 8,0$ dan 9,0. Dengan penambahan $\mathrm{NaOH}$ 0,01 $\mathrm{M}$ dan $\mathrm{H}_{2} \mathrm{SO}_{4}$ 0,01 M diukur absorbansi larutan, dan diperoleh $\mathrm{pH}$ optimum degradasi Kristal Violet.

\section{Pengaruh Penggunaan Katalis Zeolit-Y tanpa ZnO}

$100 \mathrm{~mL}$ larutan pewarna tekstil Kristal Violet 5 ppm ditambahkan 0,2;0,4;0,6;0,8; dan 1 mg Zeolit Y, kemudian dimasukkan kedalam reaktor fotoreduksi. Larutan hasil fotodegradasi dianalisis menggunakan spektrofotometer UV-Vis pada panjang gelombang $589 \mathrm{~nm}$.

\section{Pengaruh Penggunaan Katalis $\mathrm{ZnO} / \mathrm{Zeolit} \mathrm{Y}$}

Dengan menggunakan kuat cahaya, waktu dan pH optimum.100 mL larutan pewarna tekstil Kristal Violet 5 ppm ditambahkan 0,2; 0,4; 0,6; 0,8; dan $1 \mathrm{mg} \mathrm{ZnO/Zeolit} \mathrm{Y,} \mathrm{dimasukan}$ kedalam reaktor fotoreduksi. Kemudian larutanhasil fotodegradasi dianalisis menggunakan spektrofotometer UV-Vis pada panjang gelombang $589 \mathrm{~nm}$.

\section{HASIL DAN PEMBAHASAN}

\section{A. Penentuan Panjang Gelombang Optimum Larutan Kristal Violet}

Pada penelitian ini dilakukan penentuan panjang gelombang optimum senyawa Kristal Violet dalam larutan, penentuan panjang gelombang ini diperlukan untuk memenuhi persyaratan hukum Beer pada bidang analitik, ada tiga syarat utama berlakunya hukum Beer yaitu yaitu larutan harus encer, berwarna atau tidak berwarna tetapi harus jernih, tidak terjadi reaksi lanjut. 
Untuk memenuhi syarat tersebut pada penelitin ini dilakukan dengan membuat larutan Kristal Violet pada konsentrasi 50 ppm, dan ditelusur (scan) pada rentang panjang gelombang dari 400 nm hingga 600 nm menggunakan Spektrofotometer UV-Vis Merk HITACHI model U 2000.

Hasil pengukuran diperoleh panjang gelombang optimum Kristal Violet pada 589 nm.Pada panjang gelombang tersebut menunjukkan bahwa Kristal Violet dapat digunakan untuk analisis selanjutnya dalam melakukan validasi metode dan aplikasinya.

\section{B. Penyiapan Katalis Zeolit-Y-ZnO}

Zeolit-Y-ZnO dibuat dengan metode impregnasi, dengan cara melarutan $\mathrm{ZnSO}_{4}$ sebanyak 3,22 gram dalam Erlenmeyer berisi $100 \mathrm{ml}$ aquabides dan 5,0 gam zeolit-Y kemudian dilakukan pemanasan serta pengadukan selama 2 jam hal ini supaya ion $\mathrm{Zn}^{2+}$ dapat masuk ke dalam poripori zeolit, lalu ditambahkan $\mathrm{NaOH}$ untuk membuat kondisi larutan menjadi basa. Dilanjutkan dengan pemanasan serta pengadukan selama 2 jam. Kemudian dilakukan pengeringan menggunakan oven selama 24 jam pada suhu $80{ }^{\circ} \mathrm{C}$ agar zeolit-Y-ZnO terpisah dari larutannya. Hasil yang diperoleh kemudian dihaluskan hingga menghasilkan serbuk dan dikalsinasi selama 2 jam (setelah suhu tanur stabil) pada suhu $600^{\circ} \mathrm{C}$ proses kalsinasi sendiri dilakukan agar senyawa organik yang terdapat pada rongga terurai.

\section{Karakterisasi Katalis Zeolit-Y-ZnO}

\section{X-Ray Diffraction (XRD)}

\section{a. Karakteriasi Katalis Zeolit-Y-ZnO dengan XRD}

Katalis zeolit-Y-ZnO dianalisis dengan metode XRD pada sudut $60{ }^{\circ} \mathrm{C}$, analisis dilakukan di Laboratorium Metalurgi Institut Teknologi Surabaya, Surabaya. Karakterisasi katalis zeolit-Y$\mathrm{ZnO}$ dengan XRD bertujuan untuk mengidentifikasi struktur, fasa katalis, serta pembentukan fasa kristalin atau amorf pada katalis zeolit-Y-ZnO berdasarkan letak sudut $0-60^{\circ}$. Hasil karakterisasi XRD setelah kalsinasi dapat dilihat pada Gambar 1.

Dari data XRD zeolit-Y-ZnO yang diperoleh telihat bahwa muncul puncak yaitu pada sudut $2 \theta=21,2917 ; 23,1986 ; 27,3616 ; 31,7237 ; 32,3979 ; 45,4640$; dan 56,5037. Puncak khas $\mathrm{ZnO}$ berdasarkandata standar JCPDS no. 0036-1451 muncul pada $2 \theta=31,8 ; 34,42$; 36,26; 47,54; dan 56,50, ukuran kristal katalis zeolit-Y-ZnO dihitung dengan persamaan Scherrer 
sehingga didapatkan ukuran kristal sebesar 83,173 nm. Berdasarkan perhitungan tersebut ukuran kristal berukuran nanokristal karena berada pada rentang 10-200 nm

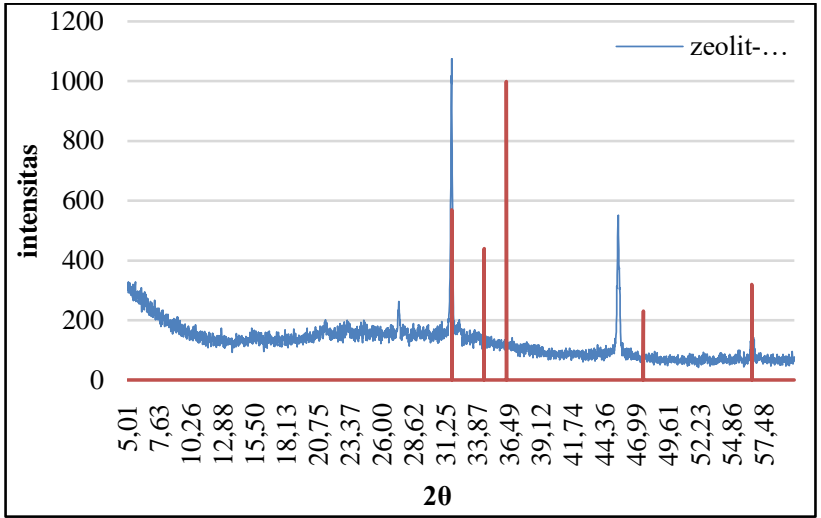

Gambar 1. Difraktogram Sinar-X katalis zeolit-Y-ZnO.

\section{Scanning Electron Microscopy (SEM)}

Karakterisasi zeolit-Y-ZnO menggunakan SEM bertujuan untuk mengetahui morfologi dan bentuk partikel pada permukaan katalis. Dalam penelitian ini, analisis SEM dilakukan terhadap katalis zeolit-Y-ZnO.

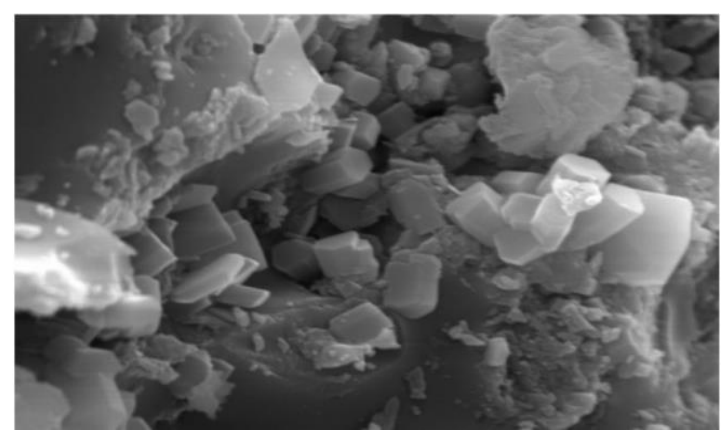

Gambar 2. Mikograf perbesaran 25000x Katalis ZnO/Zeolit Y

Pada Gambar 2 dapat terlihat bahwa bentuk morfologi katalis zeolit-Y-ZnO adalah heksagonal ditunjukkan dengan struktur yang menggumpal dengan permukaan gumpalan terdapat material berukuran kecil tersebar secara acak. Gumpalan tersebut diduga sebagai material zeolit dengan ukuran 4-13 mikrometer. Sedangkan material yang tersebar secara acak di atas permukaan gumpalan diduga sebagail Zink Oksida ( $\mathrm{ZnO}$ ) dengan ukuran 0,31-0,35 mikrometer. Dalam analisis ini menunjukkan adanya penambahan $\mathrm{ZnO}$ dilihat dari terbentuk 
atau tidak situs aktif sehingga dapat menambah kinerja katalis untuk mendegradasi pewarna tekstil Kristal Violet.

\section{Penentuan Waktu Optimum Degradasi Kristal Violet}

Proses fotodegradasi kristal violet dilakukan pengukuran kuat cahaya menggunakan luxmeter hingga mendapat 8000 Lux . Kemudian $100 \mathrm{~mL}$ larutan pewarna kristal violet 50 ppm dalam keadaan pH normal (pH 6,8) dimasukkan ke dalam reaktor fotoreduksi selama 30; 60; 90; 120; 150; 180; 210 dan 240 menit. Kemudian diambil larutan kristal violet 5 ppm setiap 30 menit sekali selama 240 menit. Selanjutnya diukur absorbansi dari masing-masing larutan dan didapatkan absorbansi pada Tabel 1.

Tabel 1. Data waktu optimum degradasi kristal violet

\begin{tabular}{ccccr}
\hline Waktu (Menit) & $\begin{array}{c}\text { Kuat } \\
\text { Cahaya } \\
(\mathbf{H z})\end{array}$ & Absorbansi & $\begin{array}{c}\text { Konsentrasi } \\
\text { Terukur }\end{array}$ & $\begin{array}{c}\text { \% Penurunan } \\
\text { Konsenrasi }\end{array}$ \\
\hline 0 & 8000 & 0,742 & 5,3638 & $0 \%$ \\
30 & 8000 & 0,723 & 5,2269 & $2,552 \%$ \\
60 & 8000 & 0,705 & 5,0972 & $2,481 \%$ \\
90 & 8000 & 0,676 & 4,8883 & $4,098 \%$ \\
120 & 8000 & 0,651 & 4,7082 & $3,684 \%$ \\
150 & 8000 & 0,617 & 4,4632 & $5,202 \%$ \\
180 & 8000 & 0,601 & 4,3479 & $2,582 \%$ \\
210 & 8000 & 0,595 & 4,3047 & $0,994 \%$ \\
240 & 8000 & 0,583 & 4,2182 & $2,008 \%$ \\
\hline Persen & & & & \\
penurunan & & & $\mathbf{2 1 , 3 5 6 \%}$ & \\
Konsentrasi & & & & \\
\hline
\end{tabular}

Pola penurunan nilai absorbansi dapat dilihat secara rinci pada Gambar 3.

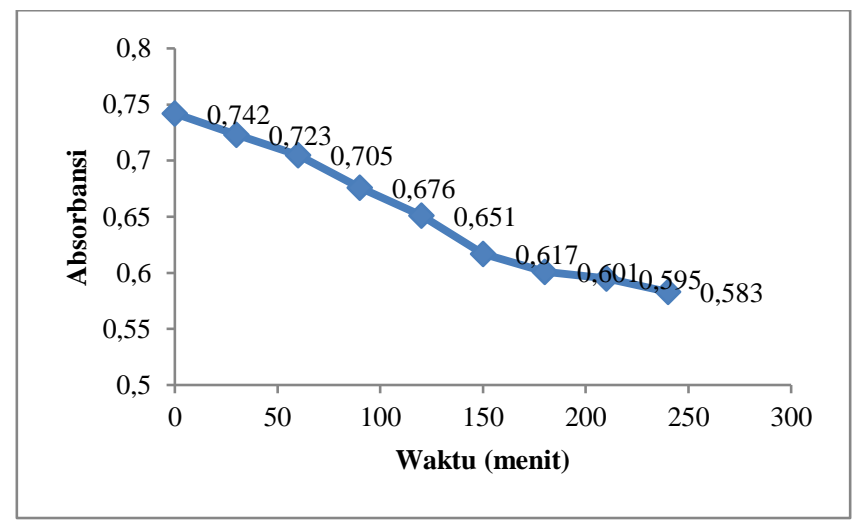

Gambar 3. Pola Penurunan Nilai Absorbansi Waktu Optimum Degradasi Kristal Violet

http://dx.doi.org/10.23960/aec.v6.i1.2021.p33-45 
Dari Tabel 4 persen penurunan konsentrasi dari 0 samapai 240 menit adalah sebesar 21,356\%. Penurunan konsentrasi yang signifikan terjadi pada proses fotoreduksi menit 120 hingga 150 terlihat nilai penurunan mencapai 5,202\%. Dari data juga menunjukkan bahwa semakin lama proses fotodegradasi terhadap kristal violet dilakukan, penurunan konsentrasi kristal violet juga terus terjadi. Peristiwa ini menunjukkan bahwa kristal violet dapat di degradasi menggunakan bantuan cahaya (foton).

\section{Penentuan pH Optimum Degradasi Kristal Violet.}

Penentuan $\mathrm{pH}$ Optimum degradasi kristal violet pertama-tama membuat larutan dengan variasi $\mathrm{pH} 5,0 ; 6,0 ; 7,0 ; 8,0 ; 9,0$, keadaan $\mathrm{pH}$ tersebut dibuat dengan cara menambahkan larutan $\mathrm{NaOH}$ atau $\mathrm{HCl}$ pada akuabides hingga $\mathrm{pH}$ yang diinginkan. Selanjutnya dilakukan fotodegradasi $100 \mathrm{~mL}$ larutan pewarna kristal violet $50 \mathrm{ppm}$ dalam reaktor fotoreduksi selama 240 menit dengan variasi pH 5,0;6,0; 7,0; 8,0; 9,0. Selanjutnya diukur absorbansi dari masingmasing larutan sebanyak 6 kali pengulangan. Berikut ini merupakan data yang didapat setelah dilakukan fotoreduksi pada kristal violetdengan variasi nilai $\mathrm{pH}$.

Tabel 2. Data Absorbansi Variasi pH Fotodegradasi Kristal Violet

\begin{tabular}{llllllllll}
\hline Ph & \multicolumn{9}{c}{ Waktu (menit) } \\
\cline { 2 - 10 } & 0 & 30 & 60 & 90 & 120 & 150 & 180 & 210 & 240 \\
\hline 5,0 & 0,737 & 0,648 & 0,622 & 0,601 & 0,589 & 0,484 & 0,479 & 0,474 & 0,458 \\
6,0 & 0,745 & 0,677 & 0,641 & 0,624 & 0,591 & 0,489 & 0,484 & 0,481 & 0,476 \\
7,0 & 0,738 & 0,709 & 0,675 & 0,652 & 0,599 & 0,495 & 0,489 & 0,485 & 0,481 \\
8,0 & 0,749 & 0,695 & 0,659 & 0,628 & 0,544 & 0,532 & 0,508 & 0,498 & 0,496 \\
9,0 & 0,745 & 0,691 & 0,657 & 0,604 & 0,589 & 0,511 & 0,505 & 0,499 & 0,497 \\
\hline
\end{tabular}

Tabel 3. Data Persen Penurunan Konsentrasi Pada Variasi $\mathrm{pH}$

\begin{tabular}{ccc}
\hline pH & $\begin{array}{c}\text { Persen } \\
\text { Penurunan } \\
\text { Konsentrasi }\end{array}$ & $\begin{array}{c}\text { Selisih Persen } \\
\text { Penurunan } \\
\text { Konsentrasi }\end{array}$ \\
\hline 9 & $33,177 \%$ & $0 \%$ \\
8 & $33,666 \%$ & $0,489 \%$ \\
7 & $34,706 \%$ & $1,04 \%$ \\
6 & $35,986 \%$ & $1,28 \%$ \\
5 & $37,728 \%$ & $1,742 \%$ \\
\hline
\end{tabular}

http://dx.doi.org/10.23960/aec.v6.i1.2021.p33-45 
Pola penurunan nilai absorbansi dapat dilihat secara rinci pada Gambar 4.

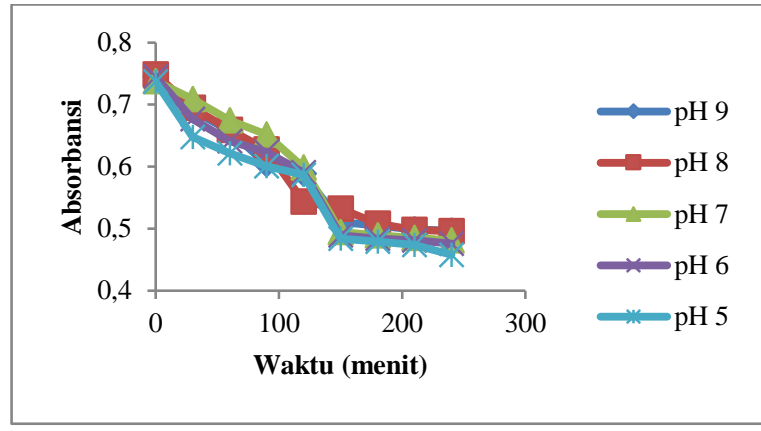

a

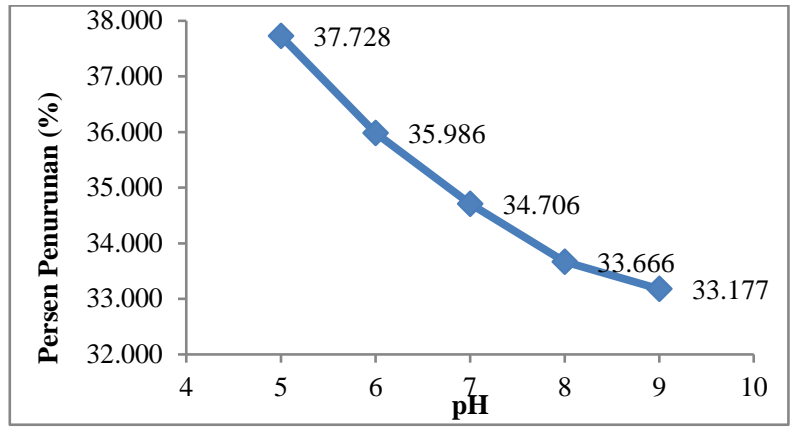

b

Gambar 4. a. Grafik pengaruh $\mathrm{pH}$ pada fotoreduksi kristal violetdi setiap variasi $\mathrm{pH}$. b. Grafik persen penurunan konsentrasi pada variasi $\mathrm{pH}$

Dari data yang telah didapatkan menunjukkan bahwa semakin asam $\mathrm{pH}$ maka akan semakin besar juga penurunan konsentrasi larutan kristal violet, sehingga keadaan $\mathrm{pH}$ sangat mempengaruhi proses degradasi dan konsentrasi kristal violet terlarut pada air. Pada penelitian ini larutan dengan $\mathrm{pH} 5$ merupakan kondisi yang menunjukkan adanya penurunan nilai konsentrasi terbesar yaitu mencapai 37,728\%.

\section{Pengaruh Penambahan Zeolit-Y}

$100 \mathrm{~mL}$ larutan pewarna tekstilkristal violet $50 \mathrm{ppm}$ ditambahkan zeolit-Y dengan variasi 0,$2 ; 0,4 ; 0,6 ; 0,8 ; 1,0 \mathrm{mg}$ zeolit-Y. Selanjutnya dilakukan fotodegradasi $50 \mathrm{~mL}$ larutan pewarna kristal violet $50 \mathrm{ppm}$ dalam reaktor fotoreduksi selama 240 menit. Selanjutnya diukur absorbansi dari masing-masing larutan. Pengukuran absorbansi larutan kristal violet dilakukan sebanyak 6 kali. Berikut ini merupakan data yang didapat setelah dilakukan fotoreduksi pada kristal violet dengan variasi penambahan Zeolit-Y.

Tabel 4. Data Absorbansi Penambahan Zeolit Y Fotodegradasi Kristal Violet

\begin{tabular}{|c|c|c|c|c|c|c|c|c|c|}
\hline \multirow{2}{*}{$\begin{array}{c}\text { Katalis } \\
(\mathrm{mg})\end{array}$} & \multicolumn{9}{|c|}{ Waktu (menit) } \\
\hline & 0 & 30 & 60 & 90 & 120 & 150 & 180 & 210 & 240 \\
\hline 0,20 & 0,731 & 0,642 & 0,607 & 0,554 & 0,487 & 0,473 & 0,461 & 0,457 & 0,453 \\
\hline 0,40 & 0,725 & 0,657 & 0,592 & 0,576 & 0,543 & 0,476 & 0,471 & 0,454 & 0,429 \\
\hline 0,60 & 0,719 & 0,660 & 0,594 & 0,539 & 0,511 & 0,427 & 0,412 & 0,407 & 0,377 \\
\hline 0,80 & 0,732 & 0,684 & 0,646 & 0,582 & 0,531 & 0,443 & 0,412 & 0,396 & 0,369 \\
\hline 1,00 & 0,736 & 0,657 & 0,624 & 0,571 & 0,542 & 0,436 & 0,401 & 0,385 & 0,342 \\
\hline
\end{tabular}


Tabel 5. Data Persentasi Penurunan Konsentrasi Pada Variasi Penambahan Zeolit-Y

\begin{tabular}{ccc}
\hline $\begin{array}{c}\text { Penambahan } \\
\text { Zeolit-Y } \\
(\mathbf{m g})\end{array}$ & $\begin{array}{c}\text { Persen } \\
\text { Penurunan } \\
\text { Konsentrasi }\end{array}$ & $\begin{array}{c}\text { Selisih Persen } \\
\text { Penurunan } \\
\text { Konsentrasi }\end{array}$ \\
\hline 0,2 & $37,90 \%$ & $0 \%$ \\
0,4 & $40,69 \%$ & $2,787 \%$ \\
0,6 & $47,40 \%$ & $6,714 \%$ \\
0,8 & $49,42 \%$ & $2,02 \%$ \\
1,0 & $53,35 \%$ & $3,93 \%$ \\
\hline
\end{tabular}

Pola penurunan nilai absorbansi dapat dilihat secara rinci pada Gambar 5.

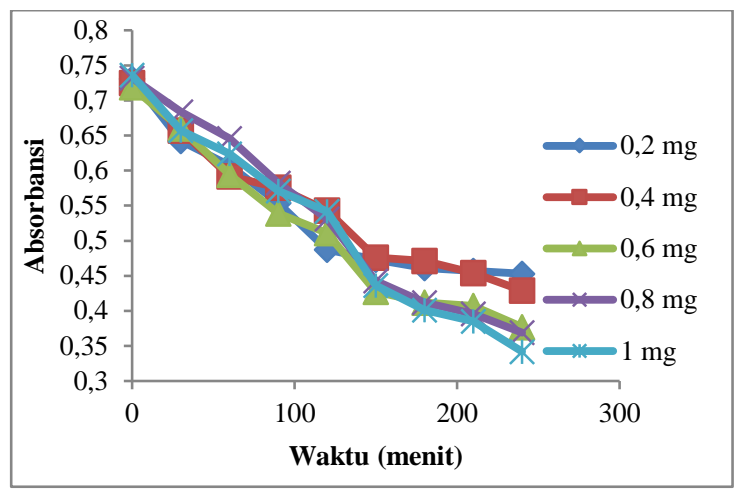

a

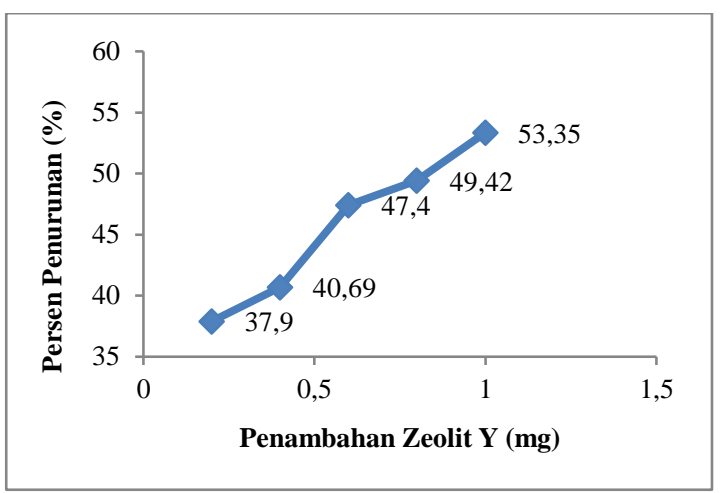

b

Gambar 5. a. Grafik pengaruh penambahan zeolit-Y terhadap fotodegradasi

b. Grafik persen penurunan konsentrasi pada variasi penambahan zeolit-Y

Dari data yang telah didapatkan menunjukkan bahwa semakin banyak penambahan zeolitY maka akan semakin besar juga penurunan konsentrasi larutan kristal violet, sehingga penambahan Zeolit-Y sangat mempengaruhi proses degradasi dan konsentrasi kristal violet terlarut pada air. Penurunan konsentrasi pewarna kristal violet sangat signifikan pada penambahan Zeolit-Y sebanyak $0,6 \mathrm{mg}$ sebesar $47,40 \%$. Ada dua faktor utama terjadinya penurunan konsentrasi kristal violetyang lebih besar dibanding tidak ada penambahan zeolit-Y yaitu, penambahan zeolit-Y menyebabkan adanya adsorpsi kristal violetoleh zeolit-Y selain itu kristal violet yang tidak teradsorpsi oleh zeolit-Y mengalami proses fotoreduksi dengan bantuan sinar tampak.

\section{Pengaruh Penambahan katalis $\mathrm{ZnO} / \mathrm{Zeolit} \mathrm{Y}$}

$100 \mathrm{~mL}$ larutan pewarna tekstilkristal violet $50 \mathrm{ppm}$ kemudian ditambahkan katalis $\mathrm{ZnO} /$ Zeolit $\mathrm{Y}$ dengan variasi 0,$2 ; 0,4 ; 0,6 ; 0,8 ; 1,0 \mathrm{mg}$. Selanjutnya dilakukan fotodegradasi 50 
$\mathrm{mL}$ larutan pewarna kristal violet $50 \mathrm{ppm}$ dalam reaktor fotoreduksi selama 240 menit. Selanjutnya diukur absorbansi dari masing-masing larutan. Pengukuran absorbansi larutan kristal violet dilakukan sebanyak 6 kali.

Tabel 6. Data Absorbansi Penambahan $\mathrm{ZnO}$ /Zeolit Y

\begin{tabular}{llllllllll}
\hline $\begin{array}{l}\text { Berat } \\
(\mathrm{mg})\end{array}$ & \multicolumn{10}{c}{ Waktu (menit) } \\
\cline { 2 - 10 } & 0 & 30 & 60 & 90 & 120 & 150 & 180 & 210 & 240 \\
\hline 0,20 & 0,746 & 0,673 & 0,595 & 0,558 & 0,491 & 0,398 & 0,375 & 0,341 & 0,307 \\
0,40 & 0,741 & 0,679 & 0,634 & 0,595 & 0,546 & 0,418 & 0,369 & 0,324 & 0,287 \\
0,60 & 0,736 & 0,641 & 0,578 & 0,483 & 0,455 & 0,334 & 0,311 & 0,265 & 0,215 \\
0,80 & 0,743 & 0,649 & 0,551 & 0,475 & 0,448 & 0,321 & 0,301 & 0,247 & 0,178 \\
1,00 & 0,739 & 0,671 & 0,597 & 0,504 & 0,493 & 0,348 & 0,286 & 0,205 & 0,131 \\
\hline
\end{tabular}

Tabel 7. Data Persen Penurunan Konsentrasi Pada Variasi Penambahan ZnO/Zeolit Y

\begin{tabular}{ccc}
\hline $\begin{array}{c}\text { Penambahan } \\
\text { ZeolitY-ZnO } \\
(\mathbf{m g})\end{array}$ & $\begin{array}{c}\text { Persen } \\
\text { Penurunan } \\
\text { Konsentrasi }\end{array}$ & $\begin{array}{c}\text { Selisih Persen } \\
\text { Penurunan } \\
\text { Konsentrasi }\end{array}$ \\
\hline 0,2 & $58,65 \%$ & $0 \%$ \\
0,4 & $61,06 \%$ & $2,412 \%$ \\
0,6 & $70,55 \%$ & $9,486 \%$ \\
0,8 & $75,79 \%$ & $5,24 \%$ \\
1,0 & $81,99 \%$ & $6,207 \%$ \\
\hline
\end{tabular}

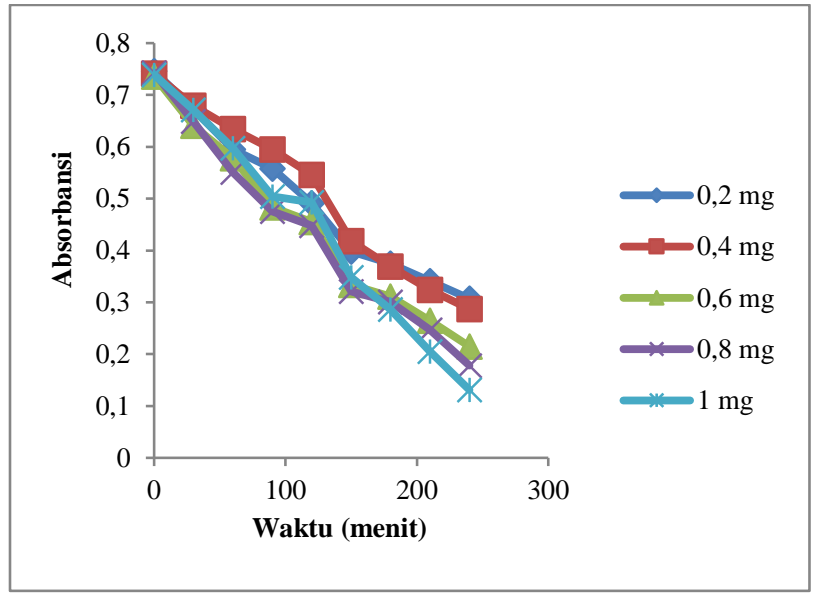

$\mathrm{a}$

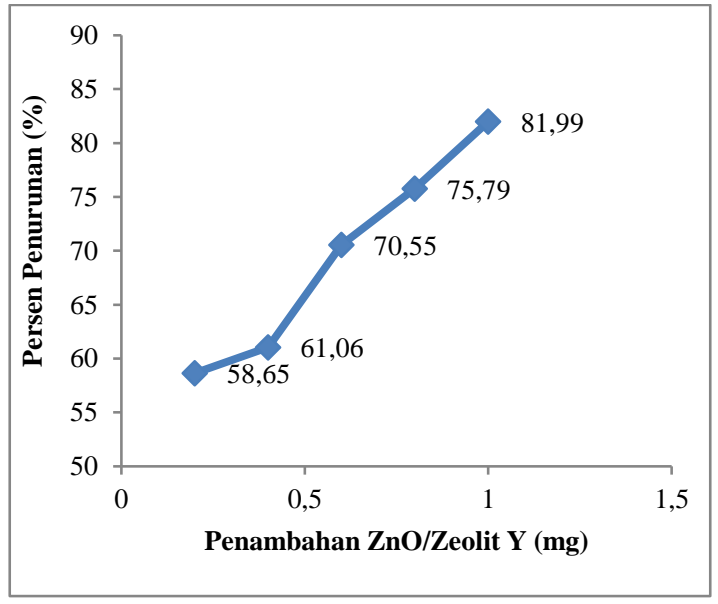

b

Gambar 6. a. Grafik pengaruh penambahan katalis $\mathrm{ZnO/Zeolit} \mathrm{Y} \mathrm{terhadap} \mathrm{fotodegradasi.}$ b. Grafik persen penurunan konsentrasi pada variasi penambahan katalis ZnO/Zeolit Y 


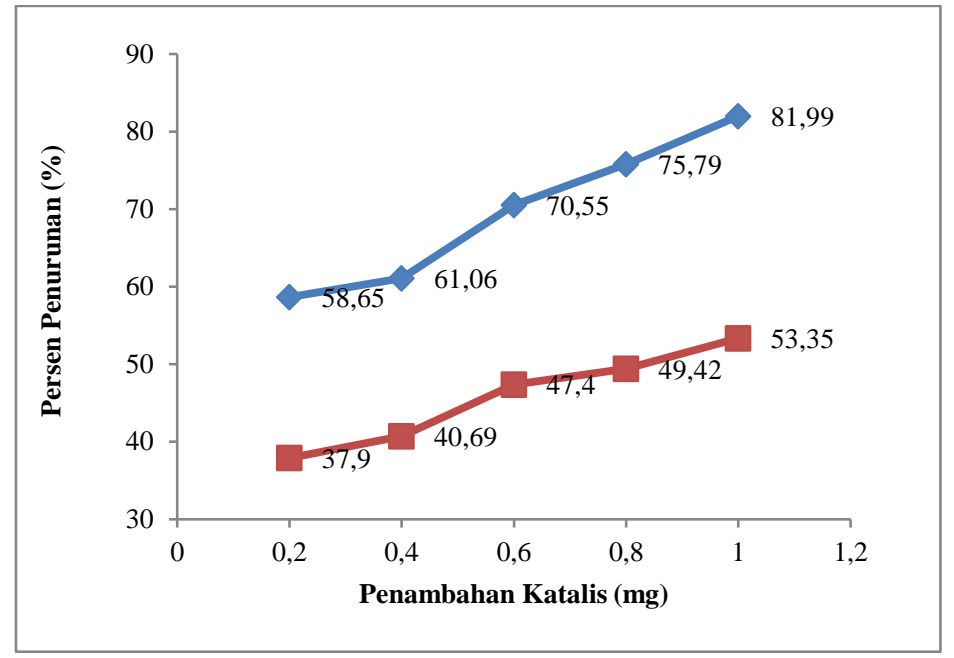

Gambar 7. Perbandingan grafik persen penurunan konsentrasi antara variasi penambahan zeolit$\mathrm{Y}$ dengan penambahan $\mathrm{ZnO} / \mathrm{Zeolit} \mathrm{Y}$

Dari data yang telah didapatkan menunjukkan bahwa semakin banyak penambahan $\mathrm{ZnO/Zeolit} \mathrm{Y} \mathrm{maka} \mathrm{akan} \mathrm{semakin} \mathrm{besar} \mathrm{juga} \mathrm{penurunan} \mathrm{konsentrasi} \mathrm{larutan} \mathrm{kristal} \mathrm{violet,}$ sehingga penambahan $\mathrm{ZnO} /$ /Zeolit $\mathrm{Y}$ sangat mempengaruhi proses degradasi dan konsentrasi kristal violet terlarut pada air. Penurunan konsentrasi pewarna kristal violet sangat signifikan pada penambahan $\mathrm{ZnO} / \mathrm{Zeolit} \mathrm{Y}$ sebanyak 0,6 mg sebesar 70,55\%.

Dari Gambar 7 terlihat bahwa katalis $\mathrm{ZnO} /$ Zeolit $\mathrm{Y}$ dapat meningkatkan efektifitas dari fotoreduksi, disebabkan karena pada saat proses fotoreduksi energi foton yang dipancarkan membuat katalis $\mathrm{ZnO} /$ Zeolit $\mathrm{Y}$ mengalami eksitasi elektron sehingga menyebabkan adanya reaksi reduksi dan menghasilkan ion hidroksil $\left(\mathrm{OH}^{-}\right)$yang mana berikatan dengan kristal violet. Sedangkan pada penambahan zeolit-Y kelimpahan ion hidroksil $\left(\mathrm{OH}^{-}\right)$pada larutan tidak sebanyak dengan adanya penambahan katalis $\mathrm{ZnO}$ /Zeolit $\mathrm{Y}$, selain itu adsorpsi kristal violetoleh zeolit-Y juga membantu menurunkan konsentrasi kristal violet terlarut. Hal itu mengakibatkan penambahan zeolit-Y menunjukkan penurunan konsentrasi kristal violet meningkat dibandingkan kondisi awal (tidak dilakukan penambahan katalis maupun zeolit dengan keadaan $\mathrm{pH}$ netral). Pada perlakuan penambahan Zeolit $\mathrm{Y}$ dan penambahan $\mathrm{ZnO} /$ Zeolit $\mathrm{Y}$ dilakukan variasi waktu kembali untuk melihat apakah ada pebedaan waktu optimum antara penambahan katalis dengan tidak ditambahkannya katalis. 


\section{KESIMPULAN}

Dari penelitian yang telah dilakukan didapatkan beberapa kesimpulan sebagai berikut:

1. Sintesis $\mathrm{ZnO} /$ Zeolit $\mathrm{Y}$ berhasil dilakukan dan didapatkan ukuran kristal ZnO/Zeolit Y sebesar $83,173 \mathrm{~nm}$.

2. Morfologi komposit $\mathrm{ZnO} /$ Zeolit $\mathrm{Y}$ menunjukkan struktur menggumpal dan terdapat material $\mathrm{ZnO}$ yang berukuran kecil tersebar secara acak pada permukaan.

3. Waktu optimum fotoreduksi pada kristal violet didapat pada menit ke 150 dengan persen penurunan konsentrasi sebesar 5,202\%.

4. $\mathrm{pH}$ optimum dari kristal violet didapatkan pada $\mathrm{pH} 5$ dengan persen penurunan konsentrasi sebesar $33,177 \%$.

5. Penambahan optimum zeolit-Y pada fotoreduksi kristal violet didapatkan pada $0,6 \mathrm{mg}$ dengan persen penurunan konsentrasi sebesar $47,40 \%$.

6. Penambahan optimum katalis $\mathrm{ZnO} /$ Zeolit $\mathrm{Y}$ pada fotoreduksi kristal violetdidapatkan pada 0,6 mg dengan persen penurunan konsentrasi sebesar 70,66\%.

\section{DAFTAR PUSTAKA}

Astuti, W., Sulistyaningsih, T., Maksiola, M., 2017, Equilibrium and kinetics of adsorption of metil violet from aqueous solutions using modified Ceiba pentandra sawdust, Asian Journal of Chemistry., 29(1), 133-138.

Blackburn, R.R. And S.M. Burkinshaw, 2002, A Greener to Cotton Deing With Excellent Wash Fastness, Green Chem., (4), 47-52.

Fatimah, I., dan Wijaya, K., 2005, Sintesis $\mathrm{TiO}_{2} /$ Zeolit Sebagai Fotokatalis Pada Pengolahan Limbah Cair Industri Tapioka Secara Adsorpsi- Fotodegradasi, TEKNO., 10(4),257-267

Rahchamani, J., Mousavi, H.Z., Behzad, M., 2011, Adsorption of metil violet from aqueous solution by polyacrylamide as an adsorbent: Isotherm and Kinetic Studies, Desalination., 267, 256-260.

Singh, S., 2009, Thesis: Electrical Transport and Optical Studies of Transition Metal Ion Doped $\mathrm{ZnO}$ and Synthesis of $\mathrm{ZnO}$ based Nanostructure by Chemical Route, Thermal Evaporation and Pulsed Laser Deposition, Departmen Of Physics Indian, Institute Of Technology Madras.

Youssef, N. A., Seham A. Shaban., Fatma A. Ibrahim., Aya S. Mahmoud., 2016, Degradation of Methyl Orange using Fenton catalytic reaction, Egypt. J. Petrol.

http://dx.doi.org/10.23960/aec.v6.i1.2021.p33-45

Anal.Environ.Chem. 